\title{
PENGARUH PENCUCIAN TERHADAP KADAR KLORIDA PADA PROSES PEMBUATAN KARAGINAN DARI RUMPUT LAUT Eucheuma cottonii
}

\author{
Farhana Septriana Rahmat ${ }^{1)}$, Srikandi ${ }^{2)^{*}}$, RTM Sutamihardja ${ }^{1)}$ \\ ${ }^{1)}$ Program Studi Kimia, Fakultas MIPA, UNB Bogor \\ ${ }^{2)}$ Progam Studi Biologi, Fakultas MIPA, UNB Bogor \\ Jl. K.H. Sholeh Iskandar Km. 4 Cimanggu, Tanah Sareal, Bogor 16166 \\ Telp. 0251-8340217, 7535605 \\ *e-mail: sriuus@yahoo.co.id
}

\section{ABSTRACT \\ Washing Effects of Chloride Content in Process of Making Carrageenan of Seaweed, Eucheuma cottonii}

\begin{abstract}
This study was conducted experimentally using Completely Randomized Design (CRD) with three (3) of standard treatments and three (3) replications. Stages of treatments included: Extraction of seaweed with three stages: extraction of seaweed with normal washing process, the twice extraction of the seaweed with laundering at the beginning, and four times extraction of the seaweed with the washing at the end. Drying of seaweed extraction, milling of dried seaweed to be come carrageenan, and filtering. Carrageenan screening results conducted to determine the yield, test physical parameters such as viscosity, $\mathrm{pH}$, water content, the gel strength, and ash content. And also test the chemical parameters such as levels of sulphate and chloride levels (as cleaning KCl based). The results showed that the washing process four times in the end give chloride levels (as KCl based cleaning) was lowest with an average of 0,16\%, compared to the treatment washing process twice in the beginning with an average of $0,33 \%$. And the manual process of $\mathrm{KCl}$ based cleaning with an average of 0,49\% therefore the normal process of providing value levels of chloride as $\mathrm{KCl}$ based cleaning was the highest. The results of the study concluded that the washing process at the beginning and at the end, affect the chloride levels based cleaning obtained at below $2 \%$. The washing process that can be used for the manufacture of carrageenan of the seaweed (Eucheuma cottonii) were the best in the washing process four times at the end.
\end{abstract}

Keywords: Eucheuma cottonii, leaching, chloride, carrageenan

\begin{abstract}
ABSTRAK
Penelitian ini dilaksanakan secara eksperimen dengan menggunakan metode Rancangan Acak Lengkap (RAL) dengan 3 (tiga) taraf perlakuan masing-masing 3 (tiga) kali ulangan. Tahapan kerja meliputi: Ekstraksi rumput laut dengan tiga tahapan yaitu ekstraksi rumput laut dengan proses pencucian normal, ekstraksi rumput laut dengan pencucian di awal sebanyak dua kali, dan ekstraksi rumput laut dengan pencucian di akhir sebanyak empat kali. Pengeringan hasil ekstraksi rumput laut, penggilingan rumput laut kering hingga menjadi karaginan, dan penyaringan. Hasil penyaringan karaginan dilakukan penentuan rendemen, uji parameter fisik seperti viskositas, $\mathrm{pH}$, kadar air, kekuatan gel, dan kadar abu. Serta uji parameter kimia seperti kadar sulfat dan kadar klorida sebagai $\mathrm{KCl}$ dry based. Hasil yang diperoleh menunjukkan bahwa perlakuan proses pencucian empat kali di akhir memberikan nilai kadar klorida sebagai $\mathrm{KCl}$ dry based terendah dengan rata-rata $0,16 \%$, dibandingkan dengan perlakuan proses pencucian dua kali di awal dengan rata-rata $0,33 \%$, dan proses manual (sebagai $\mathrm{KCl}$ dry based) dengan nilai rata-rata $0,49 \%$, jadi proses normal memberikan nilai kadar klorida (sebagai $\mathrm{KCl}$ dry based) yang menghasilkan nilai tertinggi. Hasil penelitian disimpulkan bahwa proses pencucian di awal dan di akhir, berpengaruh terhadap kadar klorida dry based yang diperoleh yaitu di bawah $2 \%$. Proses pencucian yang dapat digunakan untuk pembuatan karaginan dari rumput laut Eucheuma cottonii yang terbaik yaitu proses pencucian empat kali di akhir.
\end{abstract}

Kata kunci : Eucheuma cottonii, pencucian, klorida, karaginan 



\section{PENDAHULUAN}

Rumput laut merupakan jenis tanaman perairan yang saat ini telah banyak dibudidayakan, salah satunya adalah Euchema cottonii. Jenis ini mempunyai nilai ekonomis yang penting karena digunakan sebagai penghasil karaginan. Dalam dunia industri dan perdagangan karaginan mempunyai manfaaat yang sama dengan agar-agar dan alginat, karaginan dapat digunakan sebagai bahan baku industri farmasi, kosmetik, makanan, dan lain-lain (Mubarak et al., 1990).

Ekstraksi karaginan dari rumput laut Eucheuma pada prinsipnya merebus rumput laut dalam larutan alkali kemudian disaring, dijendalkan, dipres dan dikeringkan kembali. Ekstraksi dipengaruhi beberapa faktor antara lain lama proses ekstraksi dan temperatur ekstraksi. Proses ekstraksi dengan alkali mempunyai fungsi untuk membantu ekstraksi polisakarida menjadi lebih sempurna sehingga dapat meningkatkan kekuatan gel (Towle, 1973).

Kadar klorida dalam karaginan ditentukan oleh asal rumput laut, jenis rumput laut dan proses ekstraksinya. Faktor yang paling menentukan adalah proses ekstraksinya. Ekstraksi karaginan pada umumnya menggunakan larutan alkali (perlakuan alkali). Larutan alkali yang banyak digunakan adalah senyawa basa kuat $(\mathrm{KOH} / \mathrm{NaOH})$. Proses ekstraksi menggunakan basa kuat adalah yang paling berpeluang menyebabkan tingginya kadar klorida dalam karaginan. Hal ini disebabkan residu $\mathrm{KOH} / \mathrm{NaOH}$ akan berdisosiasi dalam air, sehingga akan mengikat ion klorida bebas dalam air membentuk garam $\mathrm{KCl} / \mathrm{NaCl}$. Garam ini akan berikatan dengan rumput laut (Sumiyawati, 2009).

Bahan baku utama dalam proses pembuatan karaginan adalah air. Oleh karena itu, tanpa ketersediaan air yang cukup akan sulit didapatkan produk karaginan yang bermutu tinggi (Basmal et al., 2009). Adanya garam klorida $(\mathrm{KCl} / \mathrm{NaCl})$ sebenarnya dapat dieleminasi dengan melakukan pencucian beberapa kali. Garam klorida akan larut dalam air sehingga rumput laut akan terbebas dari garam klorida atau setidaknya akan berkurang, karena ada klorida yang berikatan kuat dengan struktur karaginan (Sumiyawati, 2009).

\section{BAHAN DAN METODE}

\section{Bahan dan Alat}

Bahan-bahan yang digunakan yaitu rumput laut kering jenis Eucheuma cottonii yang dipanen dari Kecamatan Simpenan Kabupaten Sukabumi umur panen 45 hari, $\mathrm{KOH}$ teknis $\geq 85 \%$, air, air demin, $\mathrm{H}_{2} \mathrm{O}_{2}$ $30 \%, \mathrm{BaCl}_{2} \cdot 2 \mathrm{H}_{2} \mathrm{O}, \mathrm{HCl} 0,1 \mathrm{~N}, \mathrm{KCl}$ teknis, Larutan standard $\mathrm{AgNO}_{3} 0,1 \mathrm{~N}$, Indikator $\left(\mathrm{K}_{2} \mathrm{CrO}_{4}+\mathrm{K}_{2} \mathrm{Cr}_{2} \mathrm{O}_{7}\right)$.

Peralatan yang digunakan yaitu water batch, termometer, pengaduk, ekstraktor, kain belacu, mesin penggiling, penyaring mesh 40, wadah stainless steel, plastik, magnetic stirer, neraca analitik (Mettler Toledo AL 204), Muffle Furnace model XL-1, $\mathrm{pH}$ meter EUTECH, viscometer Brookfield LVT, LFRA (TAXT2 APPLICATION STUDY), penangas air, oven 202-1 AB Chansha Kaiyuan Instrument Co., Ltd, lemari es, buret, cawan porselen, dan alat-alat gelas lainnya.

\section{Prosedur Penelitian}

\section{Proses Pencucian}

\section{a. Proses Pencucian Normal}

Rumput laut Eucheuma cottonii ditimbang $\pm 100 \mathrm{~g}$, kemudian rumput laut dipotong menjadi ukuran 4-5 cm dan dicuci dengan cara melewati air menuju ekstraktor yang sudah terisi larutan $\mathrm{KOH} 7 \%$. Euchema cottonii diekstraksi dengan larutan $\mathrm{KOH} 7 \%$ dengan temperatur $80^{\circ} \mathrm{C}$ selama 3 jam (Basmal, 2003). Perbandingan pelarut dan bahan baku $20 \mathrm{~mL}: 1 \mathrm{~g}$ (Yasita et.al., 2009). Hasil ekstraksi dicuci dengan air selama 30 menit dengan adanya penambahan $\mathrm{H}_{2} \mathrm{O}_{2}$. Hasil ekstraksi yang telah dicuci ditiriskan dan siap untuk dikeringkan menggunakan oven dengan temperatur $40^{\circ} \mathrm{C}$ atau dengan sinar matahari.

Rumput laut kering dihaluskan hingga menjadi tepung, kemudian disaring dengan ukuran 40 mesh. Hasil penyaringan diuji parameter fisik (viskositas, $\mathrm{pH}$, kekuatan gel, kadar air, dan kadar abu) dan 
uji parameter kimia (kadar sulfat dan kadar $\mathrm{Cl}$ sebagai $\mathrm{KCl}(\mathrm{db}))$.

\section{b. Proses Pencucian Rumput Laut Dua Kali di Awal}

Rumput laut Eucheuma cottonii ditimbang $\pm 100 \mathrm{~g}$, kemudian rumput laut dipotong menjadi ukuran $4-5 \mathrm{~cm}$ dan dimasukkan ke dalam wadah pencucian. Rumput laut dicuci dengan air selama 15 menit, kemudian rumput laut ditiriskan dan dimasukkan kembali ke wadah pencucian selama 15 menit. Rumput laut ditiriskan dan dimasukkan ke dalam ekstraktor yang

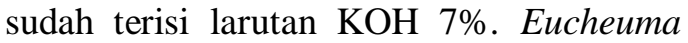
cottoni diekstraksi dengan larutan $\mathrm{KOH} 7 \%$ dengan temperatur $80^{\circ} \mathrm{C}$ selama 3 jam (Basmal, 2003). Perbandingan pelarut dan bahan baku $20 \mathrm{~mL}$ : 1 g (Yasita et.al., 2009). Hasil ekstraksi dicuci dengan air selama 30 menit dengan adanya penambahan $\mathrm{H}_{2} \mathrm{O}_{2}$. Hasil ekstraksi yang telah dicuci ditiriskan dan siap untuk dikeringkan menggunakan oven dengan temperatur $40^{\circ} \mathrm{C}$ atau dengan sinar matahari.

Rumput laut kering dihaluskan hingga menjadi tepung, kemudian disaring dengan ukuran 40 mesh. Hasil penyaringan diuji parameter fisik (viskositas, $\mathrm{pH}$, kekuatan gel, kadar air, dan kadar abu) dan uji parameter kimia (kadar sulfat dan kadar $\mathrm{Cl}$ sebagai $\mathrm{KCl}(\mathrm{db}))$.

\section{c. Proses Pencucian Rumput Laut Empat Kali di Akhir \\ Rumput laut Eucheuma cottonii} ditimbang $\pm 100 \mathrm{~g}$, kemudian rumput laut dipotong menjadi ukuran 4-5 cm dan dicuci dengan cara melewati air menuju ekstraktor yang sudah terisi larutan $\mathrm{KOH} 7 \%$. Eucheuma cottoni diekstraksi dengan larutan $\mathrm{KOH} 7 \%$ dengan temperatur $80^{\circ} \mathrm{C}$ selama 3 jam (Basmal, 2003). Perbandingan pelarut dan bahan baku $20 \mathrm{~mL}: 1 \mathrm{~g}$ (Yasita et.al., 2009). Hasil ekstraksi dicuci dengan air selama 15 menit dengan adanya penambahan $\mathrm{H}_{2} \mathrm{O}_{2}$, ditiriskan dan dicuci kembali dengan air selama 15 menit, ditiriskan dan dicuci kembali dengan air selama 15 menit, ditiriskan dan dicuci kembali dengan air selama 15 menit. Hasil ekstraksi yang telah dicuci ditiriskan dan siap untuk dikeringkan menggunakan oven dengan temperatur $40^{\circ} \mathrm{C}$ atau dengan sinar matahari.

Rumput laut kering dihaluskan hingga menjadi tepung, kemudian disaring dengan ukuran 40 mesh. Hasil penyaringan diuji parameter fisik (viskositas, $\mathrm{pH}$, kekuatan gel, kadar air, dan kadar abu) dan uji parameter kimia (kadar sulfat dan kadar $\mathrm{Cl}$ sebagai $\mathrm{KCl}(\mathrm{db}))$.

\section{Rendemen (FMC Corp, 1977)}

Rendemen karaginan sebagai hasil ekstraksi dihitung berdasarkan rasio antara berat karaginan yang dihasilkan dengan berat rumput laut.

$$
\text { Rendemen }(\%)=\frac{\text { Bobot ker ing karaginan }}{\text { Bobot rumput laut }} \times 100 \%
$$

\section{Uji Parameter Fisik}

\subsection{Kadar Air (Sudarmadji et al., 1997)}

Sampel karaginan ditimbang $1 \mathrm{~g}$ dalam cawan bersih yang telah ditera, dikeringkan dalam oven pada temperatur $100-105^{\circ} \mathrm{C}$ selama 3 jam. Cawan yang berisi sampel didinginkan di dalam desikator selama 30 menit lalu ditimbang hingga beratnya konstan. Kadar air adalah selisih massa cawan awal dikurangi massa cawan dikurangi massa cawan akhir.

Kadar air $(\%)=\frac{\text { kehilangan bobot }(g)}{\text { berat awal sampel }(g)} \times 100 \%$

\subsection{Analisis pH}

$\mathrm{pH}$ meter dikalibrasi dengan menggunakan $\mathrm{pH}$ standar 7 dan 10 . Setelah suhu $60^{\circ} \mathrm{C}$, larutan sampel diukur dengan $\mathrm{pH}$ meter. Hasil analisis dicatat.

\subsection{Analisis Viskositas (FMC Corp, 1977)}

Sampel ditimbang sebanyak 7,5 g ke dalam beaker glass $500 \mathrm{~mL} .500 \mathrm{~mL}$ aquadest ditambahkan ke dalam beaker glass $500 \mathrm{~mL}$ berisi sampel.Beaker glass berisi larutan sampel tersebut ditempatkan di atas hot plate atau heating jacket sambil terus diaduk 
dengan magnetic atau over head stirrer hingga homogen, dan dipanaskan hingga suhu mencapai $\pm 78^{\circ} \mathrm{C}$. Suhu tersebut dijaga selama beberapa waktu.Viskositas diukur pada suhu $75^{\circ} \mathrm{C}$ menggunakan Viscometer Brookfield. Hasil analisis dicatat.

\subsection{Analisis Kekuatan Gel (FMC Corp, 1977)}

Sampel karaginan sebanyak $3 \mathrm{~g}$ dilarutkan dengan $197 \mathrm{~g}$ air. Berat semua larutan ditetapkan menjadi $200 \mathrm{~g}$ sehingga konsentrasi larutan menjadi $1,5 \%$ (b/b). Larutan lalu dipanaskan di atas hot plate dengan pengadukan secara teratur sampai temperatur $80^{\circ} \mathrm{C}$ atau temperatur gelatinisasi yaitu suhu dimana larutan polisakarida menjadi lebih kental karena kemampuan mengikat air.

Larutan panas dimasukkan kedalam cetakan berdiameter kira-kira $4 \mathrm{~cm}$ dan dibiarkan pada suhu $10^{\circ} \mathrm{C}$ (suhu pendingin) selama $\pm 12 \mathrm{jam}$. Setelah membentuk gel. kekuatannya diukur dengan alat $T X$ texture analyzer.

\subsection{Analisis Kadar Abu (AOAC, 1995)}

Sampel karaginan sebanyak $2 \mathrm{~g}$ dimasukkan ke dalam cawan porselen yang telah dikeringkan dan diketahui beratnya, kemudian dipijarkan di tanur pada temperatur $600^{\circ} \mathrm{C}$ selama 6 jam. Cawan beserta abu didinginkan dalam desikator kemudian ditimbang.

Kadar abu $(\%)=\frac{\text { Bobot abu }}{\text { Bobot sampel }} \times 100 \%$

\section{Uji parameter kimia}

\subsection{Analisis Kadar Klorida Sebagai Kcl Dry Based (Cybercolloids, 2009)}

Kappa karaginan ditimbang dengan tepat sebanyak $500 \mathrm{mg}$ ke dalam erlemeyer $250 \mathrm{~mL}$ (dicatat beratnya). Sebanyak $50 \mathrm{~mL}$ aquadest ditambahkan ke dalam erlemeyer, kemudian diaduk menggunakan magnetic stirrer selama lima menit hingga homogen. Larutan indikator $\left(\mathrm{K}_{2} \mathrm{CrO}_{4}+\mathrm{K}_{2} \mathrm{Cr}_{2} \mathrm{O}_{7}\right)$ sebanyak
$1 \mathrm{~mL}$ ditambahkan ke dalam erlemeyer. Sampel dititrasi dengan perak nitrat $\left(\begin{array}{lll}\mathrm{AgNO}_{3} & 0,1 & \mathrm{~N}\end{array}\right)$ sampai terbentuk endapan merah bata. Volume titar dicatat dan dihitung kadar $\mathrm{Cl}$ dan $\mathrm{KCl}$ (db).

\subsection{Analisis Kadar Sulfat (Wiratni $e t$ al., 2010)}

Sampel karaginan ditimbang sebanyak $0,5 \mathrm{~g}$ dan dimasukkan ke dalam labu erlemeyer yang ditambahkan $50 \mathrm{~mL} \mathrm{HCl} 0,1 \mathrm{~N}$ selama 15 menit pada temperatur didih. Selanjutnya ditambahkan $10 \mathrm{~mL}$ larutan $\mathrm{BaCl}_{2} \quad 0,25 \mathrm{M}$ di atas penangas air selama 5 menit. Larutan didinginkan selama 5 jam. Endapan yang terbentuk disaring dengan kertas saring tak berabu dan dicuci dengan akuades mendidih hingga bebas klorida, kemudian dibakar dalam furnace pada temperatur $700^{\circ} \mathrm{C}$ selama 1 jam. Berat abu putih merupakan berat $\mathrm{BaSO}_{4}$, kemudian dihitung kadar sulfat.

\section{Rancangan Percobaan}

Rancangan percobaan yang digunakan adalah Rancangan acak lengkap dengan tiga taraf perlakuan masing-masing tiga kali ulangan yaitu ekstraksi rumput dengan proses pencucian normal, ekstraksi rumput laut dengan pencucian di awal sebanyak dua kali, dan ekstraksi rumput laut dengan pencucian di akhir sebanyak empat kali memiliki model sebagai berikut:

$\mathrm{Y}_{\mathrm{ij}} \quad=\mu+\tau_{\mathrm{i}}+\varepsilon_{\mathrm{ij}}$; dimana

$\mathrm{Y}_{\mathrm{ij}} \quad=$ nilai pengamatan $\mathrm{ke}-\mathrm{i}(\mathrm{i}=1,2,3)$

ulangan ke- $\mathrm{j}(\mathrm{j}=1,2,3)$

$\mu \quad=$ nilai tengah umum

$\tau_{\mathrm{i}} \quad=$ pengaruh perlakuan ke-i

$\varepsilon_{\mathrm{ij}} \quad=$ galat percobaan pada perlakuan ke-i ulangan ke-j

Untuk mengetahui pengaruh masing-masing perlakuan, dilakukan analisis sidik ragam (ANOVA) pada $\alpha=0,01$ dan uji lanjut wilayah berganda Duncan pada hasil analisis yang berbeda nyata. 


\section{HASIL DAN PEMBAHASAN}

\section{Proses Pencucian}

Pencucian bertujuan untuk menghilangkan kotoran-kotoran berupa pasir, kerikil, maupun jenis kotoran lainnya yang terdapat dalam rumput laut. Selain itu, pencucian juga bertujuan melarutkan bahan kimia yang ditambahakan untuk memperbaiki kualitas produk. pH larutan hasil pencucian mencapai 7, disebabkan $\mathrm{KOH}$ yang berikatan dengan rumput laut larut dalam air sehingga rumput laut akan terbebas dari $\mathrm{KOH}$ dan diduga semakin rendah nilai $\mathrm{pH}$ larutan hasil pencucian maka semakin rendah kadar klorida yang diperoleh.

Proses ekstraksi dengan alkali yaitu membantu ekstraksi polisakarida menjadi lebih sempurna dan mempercepat eliminasi 6-sulfat dari monomer menjadi 3,6-Anhydro-D-Galaktosa sehingga dapat meningkatkan kekuatan gel (Towle, 1973). Ekstraksi karaginan menggunakan $\mathrm{KOH}$ dapat berpengaruh terhadap kenaikan rendemen dan mutu karaginan yang dihasilkan (Patria, 2008).

\section{Rendemen}

Efektif dan efisiennya proses ekstraksi bahan baku untuk pembuatan karaginan dapat dilihat dari nilai rendemen yang dihasilkan. Proses pencucian dapat mempengaruhi warna rendemen karaginan yaitu pada proses pencucian empat kali menghasilkan warna yang lebih terang dibandingkan dengan proses pencucian dua kali di awal dan proses pencucian normal. Hasil rendemen karaginan dapat dilihat pada Gambar 2.

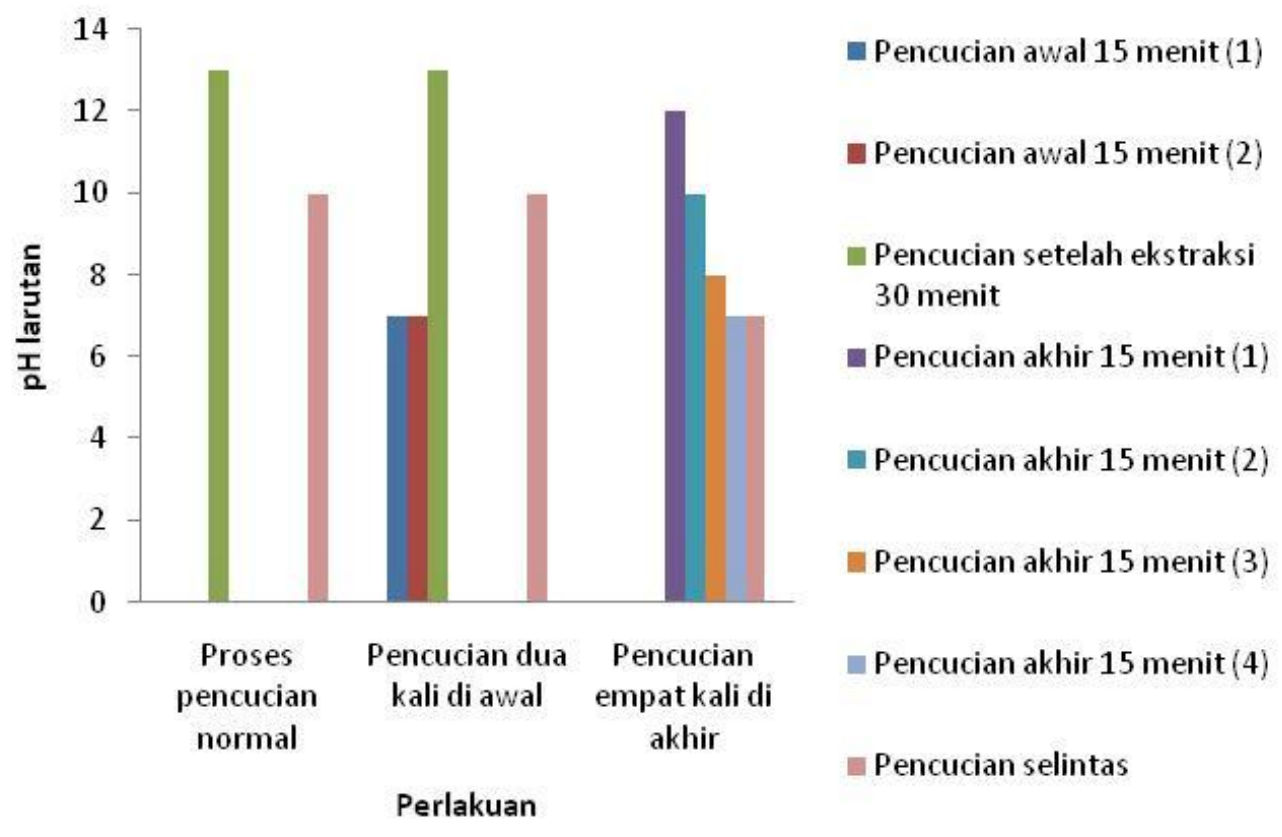

Gambar 1. Nilai pH Larutan Proses Pencucian Rumput Laut Eucheuma cottonii 


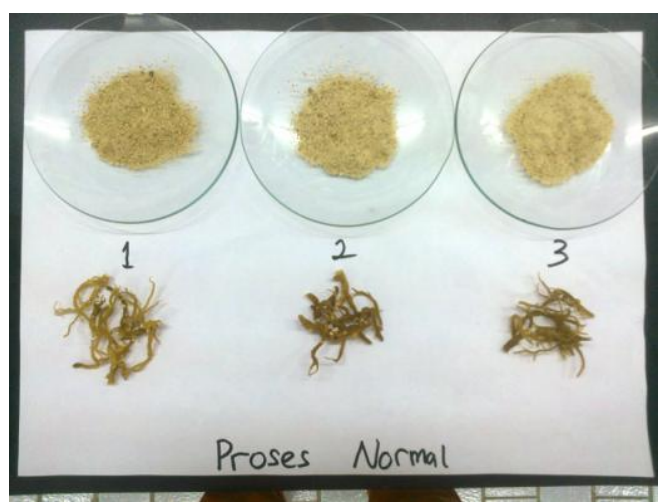

(a)

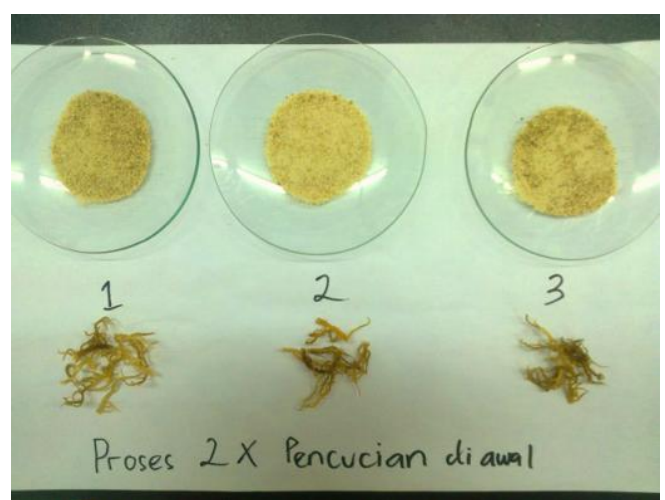

(b)

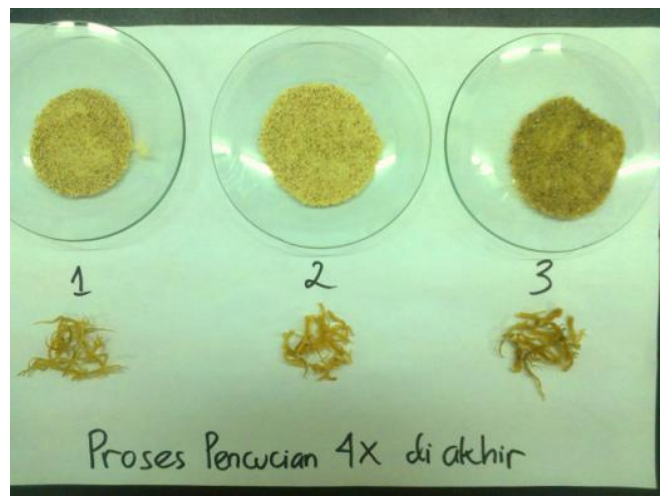

(c)

Gambar 2. Hasil Rendemen Karaginan, (a) Normal, (b) Proses 2x Pencucian di Awal, (c) Proses Pencucian 4x di akhir

Rata-rata nilai rendemen karaginan yang dihasilkan pada penelitian ini berkisar antara 20,84 - 26,60\%. Nilai rendemen tertinggi diperoleh dari perlakuan proses normal yaitu sebesar $26,60 \%$, sedangkan rendemen terendah diperoleh dari perlakuan proses pencucian dua kali di awal sebesar $20,84 \%$. Rendemen yang dihasilkan pada penelitian ini memenuhi standar persyaratan minimum rendemen karaginan yang ditetapkan oleh Departemen Perdagangan (1989), yaitu sebesar 25\% (Yasita et al., 2009).

Hasil analisis ragam menunjukkan bahwa proses pencucian memberikan pengaruh sangat nyata terhadap rendemen karaginan yang dihasilkan. Berdasarkan uji lanjut Duncan menunjukkan bahwa ratarata perlakuan proses normal memberikan nilai rendemen tertinggi dan tidak berbeda sangat nyata dengan perlakuan proses pencucian empat kali di akhir. Sedangkan perlakuan proses pencucian dua kali di awal berbeda sangat nyata dengan perlakuan proses normal dan perlakuan proses pencucian empat kali di akhir.

Pengaruh modifikasi pencucian terhadap rendemen karaginan Eucheuma cottonii yang dihasilkan dapat dilihat pada Gambar 3. Berdasarkan Gambar 3 terlihat bahwa rendemen karaginan mengalami penurunan dengan adanya pengaruh pencucian. Hasil rata-rata rendemen berdasarkan pengaruh pencucian menunjukkan bahwa perlakuan pencucian dua kali di awal mengandung rendemen lebih rendah dibandingkan perlakuan proses pencucian empat kali di akhir dan proses normal. Hal ini diduga semakin banyak pencucian di awal maka nilai rendemen semakin rendah karena semakin banyak kandungan karaginan yang terbuang dalam rumput laut selama proses pencucian. 


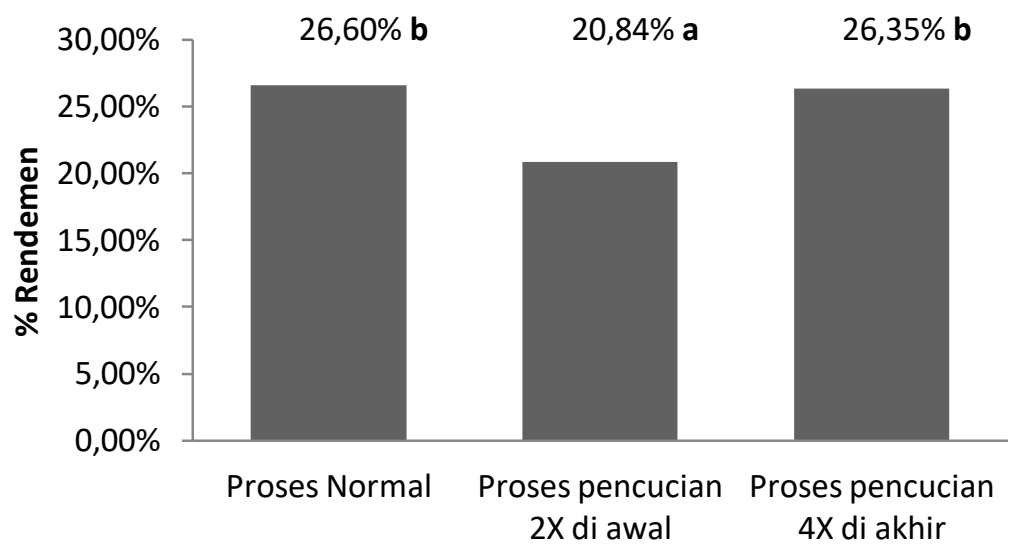

Gambar 3. Pengaruh Modifikasi Pencucian terhadap Rendemen Karaginan

Selain itu dalam proses pembuatan karaginan, rumput laut diekstraksi dalam larutan alkali $7 \%$ selama 3 jam pada temperatur $80-85^{\circ} \mathrm{C}$. Dengan proses seperti ini diduga rumput laut yang mengalami perlakuan pencucian dua kali di awal mengalami kerusakan pada bagian dinding sel, dan adanya perlakuan pencucian setelah proses ekstraksi bagian yang rusak ini terkikis atau terbuang sehingga mengurangi rendemen karaginan. Begitu juga dengan perlakuan pencucian empat kali di akhir, perlakuan pencucian ini diduga mempengaruhi keadaan fisik dari rumput laut yang menyebabkan terjadinya pengikisan pada saat pencucian.

\section{Uji Parameter Fisik}

\section{Kadar Air}

Salah satu persyaratan mutu karaginan adalah nilai kadar air yang telah dipersyaratkan baik dalam perdagangan maupun standar Food Chemical Codex (FCC, 1981) yaitu 10-12\%. Faktor yang mempengaruhi kadar air dalam produk karaginan antara lain sistem pengeringan, sifat bawaan produk seperti adanya ion yang bersifat higroskopis dan adanya faktor perlakuan dalam proses pembuatan karaginan seperti penggunaan bahan kimia $\mathrm{KOH}$ yang mudah sekali menyerap uap air dari udara ke dalam produk karaginan (Basmal, 2009). Hasil pengukuran kadar air pada penelitian ini berkisar antara 7,63-9,54\%. Kadar air karaginan yang tertinggi diperoleh dari perlakuan proses normal yaitu 9,54\%, sedangkan terendah dari perlakuan proses pencucian empat kali di akhir yaitu $7,63 \%$. Kadar air yang dihasilkan pada penelitian ini masih memenuhi kisaran standar mutu karaginan yang ditetapkan oleh FAO yaitu maksimum $12 \%$. Pengaruh pencucian terhadap kadar air karaginan rumput laut Eucheuma cottonii yang dihasilkan dapat dilihat pada Gambar 4.

Hasil analisis ragam kadar air karaginan menunjukkan bahwa proses pencucian berpengaruh sangat nyata terhadap kadar air karaginan yang dihasilkan. Uji lanjut Duncan menunjukkan bahwa perlakuan proses normal memberikan nilai kadar air tertinggi dan tidak berbeda sangat nyata dengan perlakuan proses pencucian dua kali di awal. Sedangkan perlakuan proses pencucian empat kali di akhir berbeda sangat nyata dengan perlakuan proses normal dan perlakuan proses pencucian dua kali di awal. 


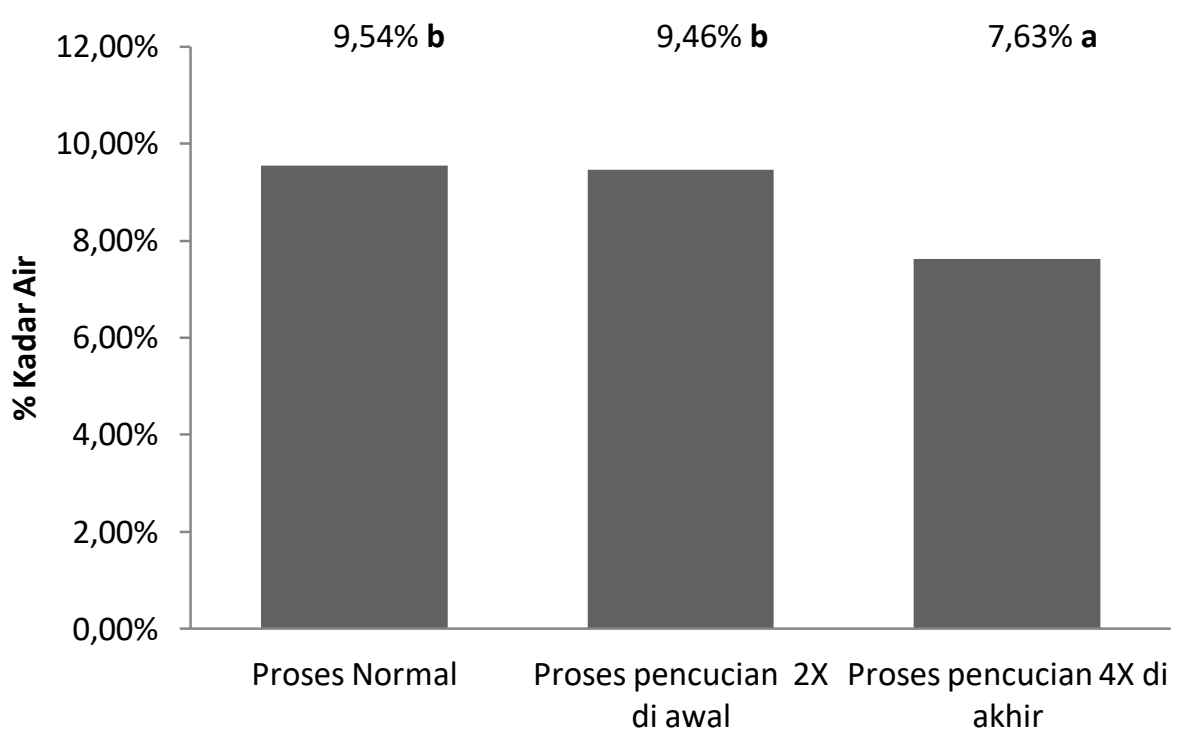

Gambar 4. Pengaruh Modifikasi Pencucian terhadap Kadar Air Karaginan

\begin{abstract}
Bedasarkan Gambar 4 terlihat bahwa kadar air karaginan mengalami penurunan dengan adanya pengaruh pencucian. Penurunan ini disebabkan karena perbandingan air yang lebih tinggi dimana jumlah air yang banyak menyebabkan jumlah air bebas juga banyak sehingga lebih mudah mengalami proses penguapan. Selain itu, senyawa-senyawa yang ikut terlarut di dalamnya ikut menguap ketika dipanaskan. Sebaliknya dengan perbandingan air yang lebih sedikit menyebabkan kadar air semakin meningkat. Hal ini disebabkan karena air yang sedikit akan terikat secara kimia sehingga sulit untuk diuapkan (Arfini, 2011). Menurut (Yasita et al., 2009) adanya penambahan $\mathrm{H}_{2} \mathrm{O}_{2}$ memberikan pengaruh terhadap kadar air karaginan yang dihasilkan. Hal ini terbukti pada perlakuan proses normal dan perlakuan proses pencucian dua kali di awal memiliki kadar air yang cukup tinggi dibandingkan dengan perlakuan proses pencucian empat kali di akhir. Hal ini disebabkan pemutih yang digunakan adalah hidrogen peroksida $\left(\mathrm{H}_{2} \mathrm{O}_{2}\right)$, dimana atom $\mathrm{H}$ dan $\mathrm{O}$ nya dapat membentuk senyawa $\mathrm{H}_{2} \mathrm{O}$ yang mengakibatkan kadar airnya bertambah. Sedangkan pada perlakuan pencucian empat kali di akhir, $\mathrm{H}_{2} \mathrm{O}_{2}$ terlarutkan oleh air saat proses pencucian sehingga atom $\mathrm{H}$
\end{abstract}

dan $\mathrm{O}$ nya tidak dapat membentuk senyawa $\mathrm{H}_{2} \mathrm{O}$.

Penambahan $\mathrm{H}_{2} \mathrm{O}_{2}$ pada proses pencucian dapat bereaksi dengan $\mathrm{OH}^{-}$dari larutan ekstraksi yaitu $\mathrm{KOH}$ yang masih melekat pada rumput laut. Reaksi yang terjadi menghasilkan $\mathrm{H}_{2} \mathrm{O}$ dan $\mathrm{HOO}^{-}$. Apabila larutan ekstraksi masih melekat pada rumput laut, maka terdapat reaksi lanjutan yaitu antara $\mathrm{HOO}^{-}$dengan $\mathrm{H}_{2} \mathrm{O}_{2}$ membentuk $\mathrm{H}_{2} \mathrm{O}, \mathrm{OH}^{-}$, dan $\mathrm{O}_{2}$.

$\mathrm{H}_{2} \mathrm{O}_{2}+\mathrm{OH}^{-} \rightarrow \mathrm{H}_{2} \mathrm{O}+\mathrm{HOO}^{-}$

Jika masih ada alkali yang melekat pada rumput laut

$\mathrm{HOO}^{-}+\mathrm{H}_{2} \mathrm{O}_{2} \rightarrow \mathrm{H}_{2} \mathrm{O}+\mathrm{OH}^{-}+\mathrm{O}_{2}$
Rendahnya kadar air karaginan
yang diperoleh diharapkan dapat
memperpanjang masa simpan karaginan (Arfini, 2011).

\section{Nilai pH}

Nilai $\mathrm{pH}$ merupakan derajat keasaman untuk menyatakan tingkat keasaaman atau basa yang dimiliki oleh suatu zat, larutan atau benda. $\mathrm{pH}$ normal memiliki nilai 7 sementara bila nilai $\mathrm{pH}>7$ menunjukkan zat tersebut memiliki sifat basa sedangkan nilai $\mathrm{pH}<7$ menunjukkan keasaman. $\mathrm{pH} 0$ menunjukkan derajat keasaman yang tinggi, dan $\mathrm{pH} 14$ menunjukkan derajat kebasaan tertinggi. 


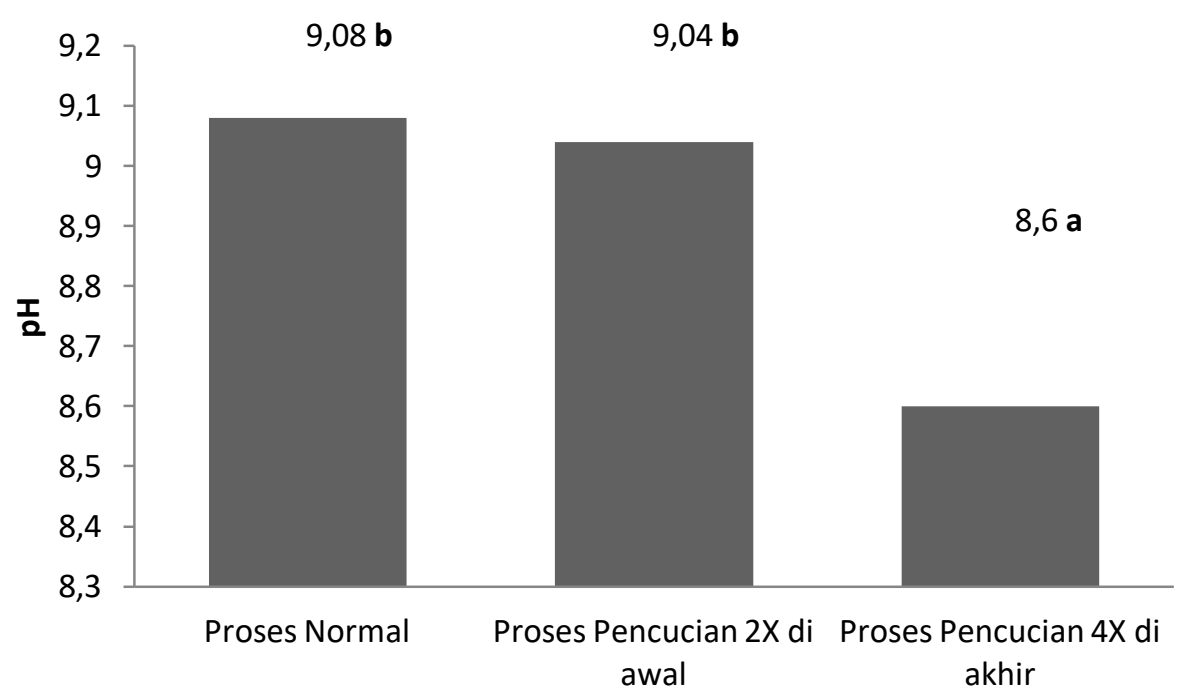

Gambar 5. Pengaruh Modifikasi Pencucian terhadap Nilai pH Karaginan

Rata-rata nilai $\mathrm{pH}$ karaginan yang diperoleh pada penelitian ini berkisar antara 8,60-9,0. Nilai $\mathrm{pH}$ terendah diperoleh dari perlakuan proses empat kali pencucian di akhir sebesar 8,60, sedangkan nilai $\mathrm{pH}$ tertinggi diperoleh dari perlakuan proses normal sebesar 9,08.

Hasil analisis ragam menunjukkan bahwa proses pencucian memberikan pengaruh sangat nyata terhadap $\mathrm{pH}$ karaginan yang dihasilkan. Uji lanjut Duncan menunjukkan bahwa perlakuan proses pencucian empat kali di akhir memberikan nilai $\mathrm{pH}$ terendah dan berbeda sangat nyata dengan perlakuan proses pencucian dua kali di awal dan perlakuan proses normal.

Pengaruh modifikasi pencucian terhadap nilai $\mathrm{pH}$ karaginan Eucheuma cottonii yang dihasilkan dapat dilihat pada Gambar 5. Dengan adanya modifikasi pencucian, maka nilai $\mathrm{pH}$ karaginan relatif menurun. Penurunan ini disebabkan karena $\mathrm{KOH}$ yang berikatan dengan rumput laut akan larut dalam air sehingga rumput laut akan terbebas dari $\mathrm{KOH}$ atau setidaknya akan berkurang. Hal ini terbukti pada perlakuan proses pencucian empat kali di akhir memiliki nilai $\mathrm{pH}$ lebih rendah dibandingkan dengan perlakuan proses pencucian dua kali di awal dan perlakuan proses normal. Semakin rendah nilai $\mathrm{pH}$ maka viskositasnya juga akan menurun, hal ini dikarenakan karena ion $\mathrm{H}^{+}$ membantu proses hidrolisa ikatan glikosidik pada molekul karaginan (Montero et al., 2002).

\section{Viskositas}

Viskositas merupakan salah satu fisik karaginan yang cukup penting. Pengujian viskositas dilakukan untuk mengetahui tingkat kekentalan karaginan sebagai larutan pada konsentrasi dan suhu tertentu. Rata-rata nilai viskositas karaginan yang dihasilkan pada penelitian ini berkisar antara 30,67 - 42,67 Cp. Nilai viskositas tertinggi diperoleh dari perlakuan proses normal sebesar 42,67 Cp, sedangkan viskositas terendah diperoleh dari perlakuan proses pencucian empat kali di akhir sebesar 30,67 Cp. Viskositas karaginan yang diperoleh pada penelitian ini memenuhi standar yang ditetapkan oleh FAO minimal $5 \mathrm{Cp}$ dan maksimal $800 \mathrm{Cp}$.

Hasil analisis ragam menunjukkan bahwa proses pencucian memberikan pengaruh sangat nyata terhadap viskositas karaginan yang dihasilkan. Uji lanjut Duncan menunjukkan bahwa perlakuan proses pencucian empat kali di akhir memberikan nilai viskositas terendah dan berbeda sangat nyata dengan perlakuan proses pencucian dua kali di awal dan perlakuan proses normal. 


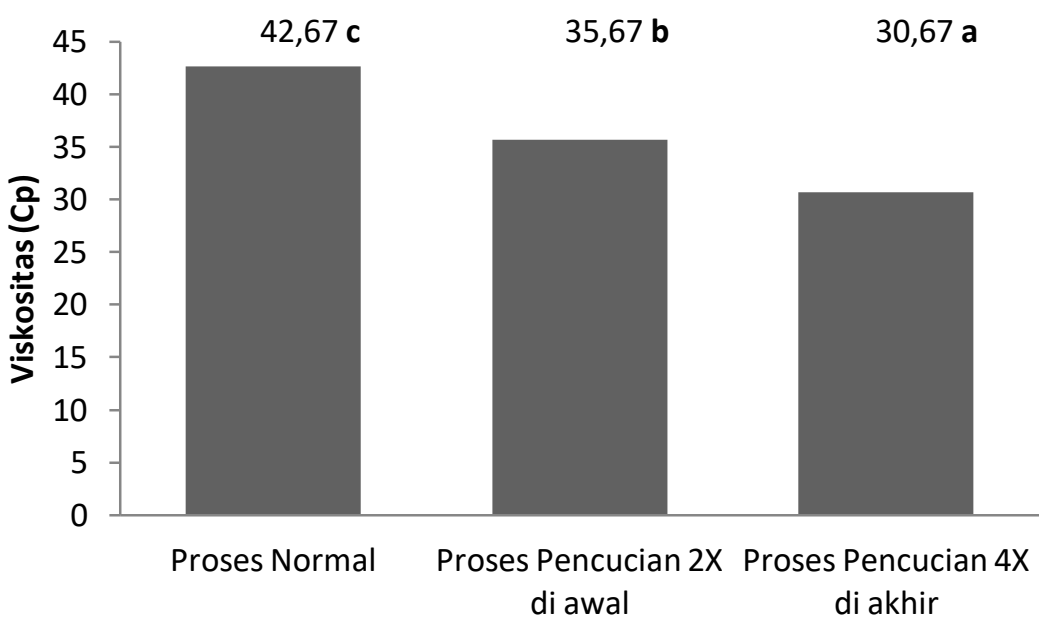

Gambar 6. Pengaruh Modifikasi Pencucian terhadap Viskositas Karaginan

Dengan adanya modifikasi pencucian maka viskositas karaginan relatif menurun (Gambar 6). Hal ini disebabkan karena kandungan sulfat yang bermuatan negatif semakin banyak melakukan tolakan (repulsion) satu sama lain sehingga air yang berada disekitar polimer jika jumlahnya lebih sedikit akan lebih mudah terimobilisasi yang menyebabkan larutan bersifat kental yang juga berarti viskositas larutan tinggi (Towle, 1973; Arfini, 2011). Hal ini terbukti pada perlakuan proses normal memiliki viskositas lebih tinggi dibandingkan dengan perlakuan proses pencucian dua kali di awal dan perlakuan proses pencucian empat kali di akhir. Tinggi rendahnya viskositas karaginan yang dihasilkan sangat dipengaruhi oleh banyaknya gugus sulfat pada rantai karaginan. Semakin tinggi viskositas menunjukkan banyaknya ion sulfat yang bereaksi dengan karaginan (Basmal et.al., 2009). Jadi, keberadaan sulfat dalam karaginan sangat mempengaruhi daya kelarutan karaginan dalam air, karena sifat sulfat yang dapat mengikat molekul air sehingga tepung karaginan yang mengandung sulfat yang tinggi akan mudah larut dalam air.

\section{Kekuatan Gel}

Kekuatan gel merupakan sifat fisik utama karaginan, karena kekuatan gel menunjukkan kemampuan karaginan dalam pembentukan gel. Kekuatan gel karaginan dinyatakan sebagai breaking force yang didefinisikan sebagai beban maksimum yang dibutuhkan untuk memecahkan matriks polimer pada daerah yang dibebani (Suheti, 2000).

Rata-rata nilai kekuatan gel karaginan yang diperoleh pada penelitian ini berkisar antara 174,57-263 gf. Nilai kekuatan gel tertinggi diperoleh dari perlakuan proses normal sebesar 263 gf, sedangkan nilai kekuatan gel terendah diperoleh dari perlakuan proses pencucian empat kali di akhir sebesar 174,57 gf.

Hasil analisis ragam menunjukkan bahwa proses pencucian memberikan pengaruh sangat nyata terhadap kekuatan gel karaginan yang dihasilkan. Uji lanjut Duncan menunjukkan bahwa perlakuan proses pencucian empat kali di akhir memberikan nilai kekuatan gel terendah dan berbeda sangat nyata dengan perlakuan proses pencucian dua kali di awal dan perlakuan proses normal.

Dengan adanya modifikasi pencucian, maka kekuatan gel karaginan relatif menurun (Gambar 7). Penurunan ini disebabkan oleh mineral-mineral terlarut yang keluar bersama cairan rumput laut pada saat proses pencucian. Beberapa mineral atau ion logam sangat mempengaruhi dalam pembentukan gel karaginan, seperti ion $\mathrm{K}, \mathrm{Ca}, \mathrm{Mg}$, dan $\mathrm{Na}$ yang dapat meningkatkan kekuatan gel (Zabik \& Aldrich, 1968). 


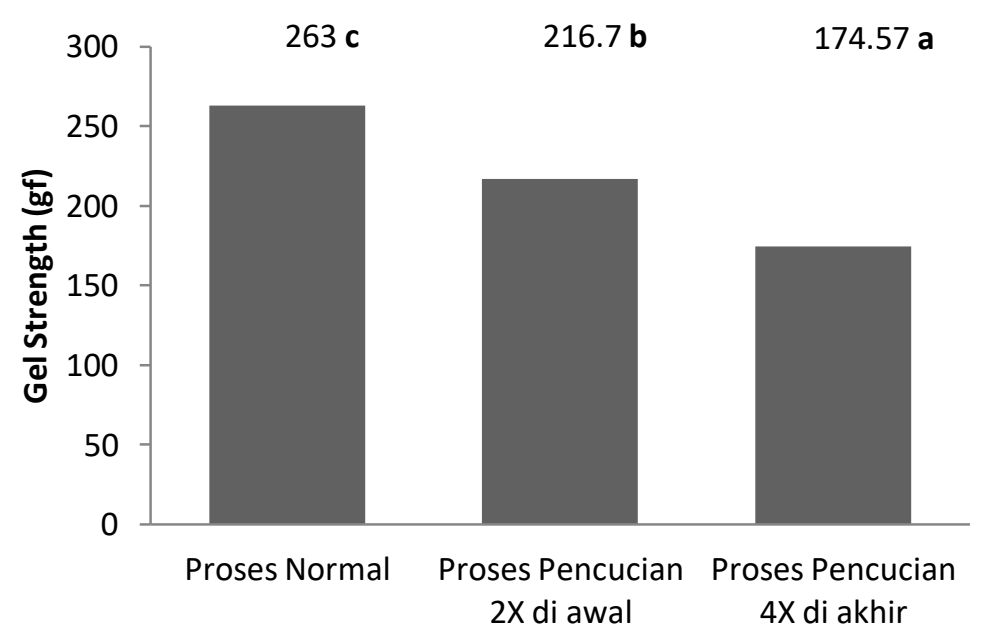

Gambar 7. Pengaruh Modifikasi Pencucian terhadap Kekuatan Gel Karaginan

Penggunaan $\mathrm{KOH}$ dalam proses ekstraksi juga mampu meningkatkan kekuatan gel kappa karaginan. Hal ini disebabkan karena kappa karaginan sensitif terhadap ion $\mathrm{K}^{+}$yang mampu meningkatkan kekuatan ionik dalam rantai polimer karaginan sehingga gaya antar molekul terlarut semakin besar yang menyebabkan keseimbangan antara ion - ion yang larut dengan ion - ion yang terikat didalam struktur karaginan dapat membentuk gel (Hakim, 2011).

\section{Kadar Abu}

Abu merupakan zat anorganik sisa hasil pembakaran suatu bahan organik. Kandungan abu dan komposisinya tergantung pada bahan dan cara pembuatannya. Kadar abu ada hubungannya dengan mineral suatu bahan (Winarno, 1990). Bahanbahan yang menguap selama proses pembakaran berupa air dan bahan volatil lainnya akan mengalami oksidasi dengan menghasilkan $\mathrm{CO}_{2}$.

Rata-rata kadar abu yang dihasilkan dari penelitian ini berkisar antara 18,520,48\%. Kadar abu terendah diperoleh dari perlakuan proses pencucian empat kali di akhir sebesar $18,5 \%$, sedangkan tertinggi dari perlakuan proses pencucian dua kali di awal sebesar 20,48\%. Hasil ini menunjukkan bahwa kadar abu yang diperoleh masih memenuhi standar mutu karaginan yang ditetapkan oleh FAO yaitu sebesar $15-40 \%$ dan FCC maksimum 35\%.

Hasil analisis ragam kadar abu karaginan menunjukkan bahwa proses pencucian berpengaruh sangat nyata terhadap kadar abu karaginan yang dihasilkan. Uji lanjut Duncan menunjukkan bahwa perlakuan proses pencucian dua kali di awal memberikan nilai kadar abu tertinggi dan berbeda sangat nyata dengan perlakuan proses normal dan perlakuan proses pencucian empat kali di akhir.

$$
\text { Kadar abu karaginan yang }
$$
dihasilkan akan menurun dengan adanya perlakuan proses pencucian empat kali di akhir (Gambar 8). Penurunan kadar abu diduga karena kandungan garam dan mineral hasil dari proses ekstraksi yaitu kation $\mathrm{K}^{+}$yang merupakan salah satu mineral dari $\mathrm{KOH}$ sebagai larutan ekstraksi terlarutkan. Sedangkan kadar abu pada perlakuan proses pencucian dua kali di awal lebih tinggi dibandingkan dengan perlakuan proses normal. Hal ini diduga saat pencucian di awal sebanyak dua kali selama 15 menit, rumput laut terlalu banyak menyerap air dan pada saat mengalami proses ekstraksi rumput laut mengeluarkan kandungan air sehingga bereaksi dengan $\mathrm{KOH}$. Kation $\mathrm{K}^{+}$yang merupakan salah satu mineral dari $\mathrm{KOH}$ sebagai larutan ekstraksi terserap ke dalam rumput laut . 


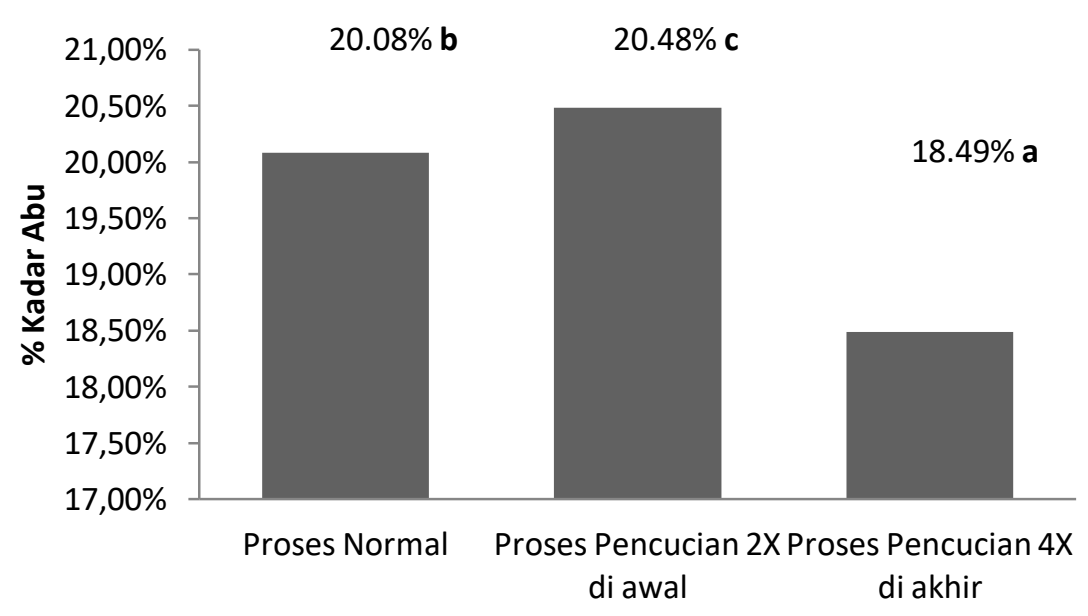

Gambar 8. Pengaruh Modifikasi Pencucian terhadap Kadar Abu Karaginan

Rumput laut termasuk bahan pangan yang mengandung mineral cukup tinggi seperti $\mathrm{Na}, \mathrm{Ca}, \mathrm{K}, \mathrm{Cl}, \mathrm{Mg}, \mathrm{Fe}, \mathrm{S}$ dan "trace elemen" terutama iodium. Hal ini diduga menyebabkan rumput laut mengandung kadar abu cukup tinggi. Selain itu rumput laut tumbuh di atas karang-karang batu dengan lingkungan bersalinitas tinggi

\section{Uji Parameter Kimia Karaginan}

\section{Kadar Klorida}

Rata-rata kadar klorida karaginan yang dihasilkan dari penelitian ini berkisar antara 0,16-0,49\%. Nilai kadar klorida terendah diperoleh dari perlakuan proses pencucian empat kali di akhir, sedangkan tertinggi dari perlakuan proses normal. Hasil ini menunjukkan bahwa kadar klorida yang diperoleh memenuhi standar mutu karaginan yang ditetapkan oleh Cybercolloids yaitu maksimum $2 \%$.

Hasil analisis ragam kadar klorida karaginan menunjukkan bahwa proses pencucian berpengaruh sangat nyata terhadap kadar klorida karaginan yang dihasilkan. Uji lanjut Duncan menunjukkan bahwa perlakuan proses pencucian empat kali di akhir memberikan nilai kadar klorida terendah dan berbeda sangat nyata dengan perlakuan proses pencucian dua kali di awal dan perlakuan proses normal.

Kadar klorida karaginan relatif menurun dengan adanya modifikasi pencucian (Gambar 9). Penurunan ini disebabkan garam klorida akan larut dalam air sehingga rumput laut akan terbebas dari garam klorida atau setidaknya akan berkurang, karena ada klorida yang berikatan kuat dengan struktur karaginan (Sumiyawati, 2009). Hal ini terbukti pada perlakuan proses pencucian empat kali di akhir memiliki kadar klorida sebagai $\mathrm{KCl}$ dry based lebih rendah dibandingkan dengan perlakuan proses pencucian dua kali di awal dan perlakuan proses normal.

\section{Kadar Sulfat}

Kadar sulfat merupakan parameter yang digunakan untuk berbagai jenis polisakarida yang terdapat dalam alga merah (Winarno, 1990). Hasil ekstraksi rumput laut dibedakan berdasarkan kandungan sulfatnya. Agar-agar mengandung sulfat tidak lebih dari 3-4\%, furcellaran 8$18 \%$ dan karaginan minimal 18\% (Moirano, 1977).

Rata-rata kadar sulfat karaginan yang dihasilkan dari penelitian ini berkisar antara 2,45-2,60\%. Nilai kadar sulfat terendah diperoleh dari perlakuan proses pencucian dua kali di awal, sedangkan tertinggi dari perlakuan proses pencucian empat kali di akhir. Hasil ini menunjukkan bahwa kadar sulfat yang diperoleh tidak memenuhi standar mutu karaginan yang ditetapkan oleh FAO dan FCC yaitu 15$40 \%$ (Gambar 10). Hasil analisis ragam kadar sulfat karaginan menunjukkan bahwa proses pencucian tidak berpengaruh sangat nyata terhadap kadar sulfat karaginan yang dihasilkan. 


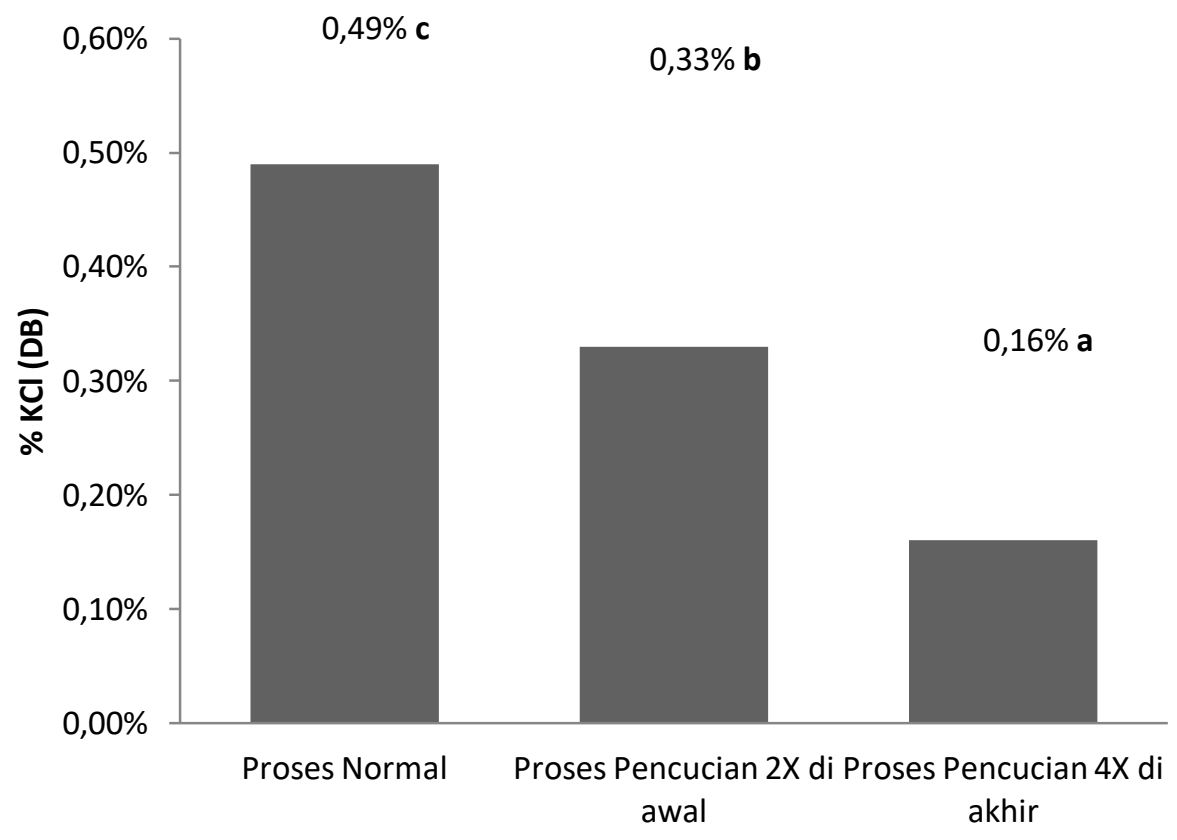

Gambar 9. Pengaruh Modifikasi Pencucian terhadap Kadar Klorida Karaginan

Kadar sulfat dipengaruhi oleh tipe karaginan, konsentrasi, kadar air, jenis dan umur panen. Kadar sulfat yang diperoleh berada dibawah standar mutu yang ditetapkan FAO yaitu sebesar $15-40 \%$. Keberadaan sulfat dalam karaginan sangat mempengaruhi daya kelarutan karaginan dalam air, karena sifat sulfat yang dapat mengikat molekul air sehingga tepung karaginan yang mengandung sulfat yang tinggi akan mudah larut dalam air. Hal ini terbukti pada perlakuan proses pencucian dua kali di awal memiliki kadar sulfat lebih rendah dibandingkan dengan perlakuan proses normal dan perlakuan proses pencucian empat kali di akhir. Karena adanya perlakuan pencucian sebanyak dua kali masing-masing selama 15 menit sebelum proses ekstraksi, kemudian juga adanya proses pencucian selama 30 menit setelah proses ekstraksi, maka sulfat yang terdapat dalam rumput laut mengikat molekul air dan ikut terlarut dengan air. Pada perlakuan proses pencucian empat kali di akhir, terjadi peningkatan kadar sulfat dibandingkan dengan perlakuan proses normal. Hal ini diduga sejumlah sulfat telah tertarik ke dalam thallus rumput laut selama proses pencucian. Pengeringan hanya bertujuan untuk mereduksi zat-zat mudah menguap sedangkan ion sulfat akan terdeposit di dalam thallus sehingga menyebabkan kadar sulfat di dalam thallus meningkat (Basmal, 2009). Karaginan yang berkualitas adalah karaginan yang memiliki kandungan sulfat rendah, sehingga dapat meningkatkan kekuatan gelnya (Murniyati, 1994). Namun dengan kandungan sulfat yang rendah, karaginan masih bisa dikonsumsi baik untuk keperluan pangan maupun keperluan non pangan (Zikrullah, 2013). 


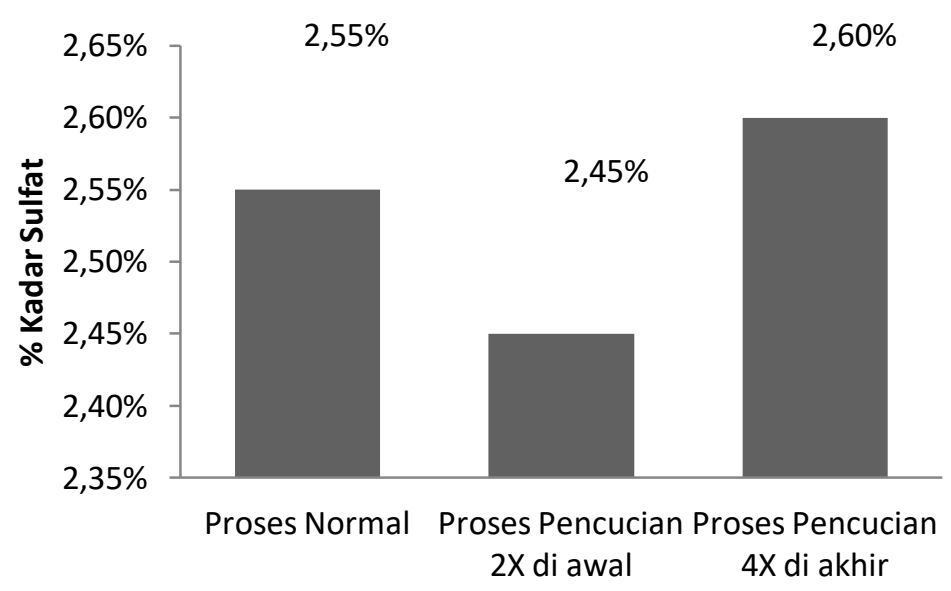

Gambar 10. Pengaruh Modifikasi Pencucian terhadap Kadar Sulfat Karaginan

\section{KESIMPULAN}

Berdasarkan hasil penelitian yang diperoleh dapat disimpulkan bahwa perlakuan proses pencucian di awal dan di akhir berpengaruh terhadap kadar klorida dry based yang diperoleh yaitu di bawah 2 $\%$. Proses pencucian yang dapat digunakan untuk pembuatan karaginan dari rumput laut Eucheuma cottonii yang terbaik yaitu proses pencucian empat kali di akhir.

\section{DAFTAR PUSTAKA}

Arfini, F. 2011. Optimasi Proses Ekstraksi Pembuatan Karaginan dari Rumput Laut Merah (E.cottonii) serta Aplikasinya sebagai Penstabil pada Sirup Markisa. Tesis. IPB. Bogor.

AOAC. 1995. Official Methods of Analysis of the Association of Official Analytical Chemist. 16th ed A.O.A.C., Inc., Arlington. Virginia.

Basmal, J., B.S.B.Utomo, B.B. Sedayu. 2009. Mutu Semirefined Carrageenan (SRC) yang Diproses Menggunakan Air Limbah Pengolahan SRC yang didaur Ulang. Jurnal Pasca Panen \& Bioteknologi Kelautan dan Perikanan. 4(1): 1-11.
Basmal J. 2003. Teknologi Pengolahan Rumput Laut Eucheuma. Pusat Riset Pengolahan Produk dan Sosial Ekonomi Kelautan dan Perikanan. Badan Riset Kelautan dan Perikanan. Jakarta.

Cybercolloids. 2006. Measurement of The Chloride Content in a Sample of Carrageenan.

Food Chemical Codex. 1981. Carrageenan. National Academy Press Washington.

Food Marine Colloids Corp (FMC Corp). 1977. Carrageenan. Marine Colloid Monograph Number One. Springfield New Jersey. USA : Marine Colloid Division FMC Corporation. New Jersey. USA.

Hakim, A. R., 2011. Pengaruh Perbandingan Air Pengekstrak, Suhu Prespitasi, Dan Konsentrasi Kalium Klorida (KCL) Terhadap Mutu Karaginan. Jurnal Pasca Panen dan Bioteknologi Kelautan dan Perikanan. 6 (1).

Moirano. A.L. 1977. Sulfate Seaweed Polysacharides dalam Food Colloids. The AVI Publ.co. Westport Conneticut: 347-381.

Montero, P. and M. P. Mateos. 2002. Effect of $\mathrm{Na}^{+}, \mathrm{K}^{+}, \mathrm{Ca}^{2+}$ on gels formed 
from fish mince containing a carrageenan or alginate. Food Hydrocolloid. 16 (4): 375-385.

Mubarak H, A. Soegiarto., Sulistyo, W.S. Atmadja. 1990. Petunjuk Teknis Budidaya Rumput Laut. Pusat Penelitian dan Pengembangan Pertanian. Jakarta.

Murniyati, J.T. Murtini, dan N. Indriati. 1994. Penyederhanaan Cara Ekstraksi Karaginan dari E. cottonii. Jurnal Penelitian Pasca Panen Perikanan. (80):23-33.

Patria, A. 2008. Pmanfaatan Karaginan Dari Rumput Laut Kappaphycus alvarezii Pada Pembuatan Dodol Kentang. Skripsi. Fakultas Perikanan dan Ilmu Kelautan, Institut Pertanian Bogor. Bogor.

Sudarmadji, S., B. Haryono dan Suhardi. 1997. Prosedur Analisis untuk Bahan Makanan dan Pertanian. Liberty. Yogyakarta.

Suheti, E. 2000. Pengaruh Penambahan $\mathrm{KCl}$ terhadap Mutu Dodol Rumput Laut. Skripsi. Fakultas Perikanan dan Ilmu Kelautan. IPB. Bogor.

Sumiyawati, E., Pahrudin. 2009. Pengukuran Kadar Klorida dalam Kappa Karaginan. Department of Research and Development PT Galic Artabahari. Bekasi.
Towle. 1973. Carrageenan. Di dalam R.L. Whistler (ed). Industrial Gum Polisacharides and Their Derivativer. AC Press. New York.

Winarno, F. G. 1990. Teknologi Pengolahan Rumput Laut. Pustaka Sinar Harapan. Jakarta.

Winarno, F. G. 1996. Teknologi Pengolahan Rumput Laut. Pustaka Sinar Harapan. Jakarta.

Wiratni, S., Distantina, Fadilah, Rochmadani, M. Fahturozzi. 2010. Seminar Rekayasa Kimia dan Proses: Proses Ekstraksi Karaginan Dari Eucheuma cottonii. ISSN: 1411-4216.

Yasita, D. dan I.D. Rachmawati. 2009. Optimasi Proses Ekstraksii pada Pembuatan Karaginan dari Rumput Laut Euchema cottonii untuk Mencapai Food Grade. Jurusan Teknik Kimia Universitas Dipenogoro.

Zabik, M.E. \& P.J. Aldrich. 1968. Gel Strength of Kappa-Carrageenan as Affected by Cations. J. Of Food Science. 33(4): 371-377.

Zikrullah, A.Z. 2013. Optimasi Perlakuan Kalium Klorida Pada Pemisahan Karaginan Dari Rumput Laut Eucheuma Cottonii. Skripsi. Fakultas MIPA. UNB. Bogor. 